\author{
E. Biondi, M. Allegrezza, S. Casavecchia, D. Galdenzi, R. Gasparri, S. \\ Pesaresi, P. Soriano, G. Tesei \& C. Blasi
}

\title{
New insight on Mediterranean and sub-Mediterranean syntaxa included in the Vegetation Prodrome of Italy
}

\begin{abstract}
Biondi, E., Allegrezza, M., Casavecchia, S., Galdenzi, D., Gasparri, R., Pesaresi, S., Soriano, P., Tesei, G. \& Blasi, C.: New insight on Mediterranean and sub-Mediterranean syntaxa included in the Vegetation Prodrome of Italy. - Fl. Medit. 25 (Special Issue): 77-102. 2015. — ISSN: 1120-4052 printed, 2240-4538 online.

The Italian Vegetation Prodrome (IVP), implemented on behalf of the Ministry of the Environment and Protection of Land and Sea (also known as MATTM) on the basis of two agreements entrusted to the Italian Botanical Society, has been drawn up to the lower level of suballiance. In the current paper, the syntaxonomical choices adopted in the description and the typification of the new syntaxa are explained through eight main conceptual issues. Among these, there are several Mediterranean and sub-Mediterranean syntaxa, which contribute to improve knowledge of the phytocoenosis biodiversity of these biogeographic areas. Indeed, these Mediterranean and sub-Mediterranean territories are the most important European areas in terms of flora, vegetation and habitats. In the past, the syntaxa of these bioclimatic and phytogeographic areas were mainly included in classes widespread over Europe and in hierarchical levels that are, in our opinion, inappropriate for describing their floristic and phytocoenotic richness. Therefore, we decided, in some cases, to raise their hierarchical level in order to promote a better and more appropriate syntaxonomical classification. The definition of such syntaxa is the result of a research carried out on various aspects of the flora, ecology and dynamic features of the plant communities; they have often considered large geographical territories, wider than Italy and, sometimes, even Europe. The case study of some syntaxa belonging to the classes Euphorbio paraliae-Ammophiletea australis, Sarcocornietea fruticosae, Festuco valesiacae-Brometea erecti, Trifolio medii-Geranietea sanguinei, Rhamno catharticae-Prunetea spinosae are shown.
\end{abstract}

Key words: bioclimatology, sand dune vegetation, wetland vegetation, ecotone vegetation, dry grassland vegetation, Italy, plant ecology, syndynamic, syntaxonomy, methodological classification.

\section{Introduction}

The aim of this paper is to highlight the logic and conceptual lines leading to the implementation of the Italian Vegetation Prodrome (IVP) in the current state of the art (available on the Italian Botanical Society (IBS) website in a special forum that is still partly upgradeable: 
http://www.prodromo-vegetazione-italia.org). The IVP project has been carried out in the framework of two agreements entrusted to the Italian Botanical Society by the Ministry of the Environment and Protection of Land and Sea (also known as MATTM) and coordinated by Edoardo Biondi and Carlo Blasi. The first of these agreements, which began in 2012 and ended in 2013, involved the implementation of the prodrome up to the syntaxonomical level of alliance (Biondi \& al. 2014b). The second agreement, started in 2014 and ended in April 2015 , concerned the addition of suballiances and the improvement of what had been produced during the first phase through changes and updating of syntaxa, some of them newly described and recently typified in accordance with the ICPN rules.

Currently the prodrome consists of 75 classes, two subclasses, 175 orders, eight suborders, 403 alliances and 89 suballiances; the state of the art of the prodrome is available on the fore-mentioned website of the Italian Botanical Society.

The IVP is the first comprehensive survey of the vegetation of Italy involving the entire country. It is a checklist of syntaxa whose valid names and synonyms are provided.

For the upper syntaxonomic hierarchical levels, a synthetic diagnostic sentence is provided while for the alliances and suballiances 482 original sheets are provided that give insight on the ecology, geographical distribution, floristic composition, syndynamic features, connections to habitats of Community interest, conservation status and management, presence in National Parks, and specific literature. The work ends with a rich glossary that helps the reader to understand the technical and scientific terms used.

The Mediterranean and sub-Mediterranean syntaxa, often newly described or lately reassessed, play a very important role in the IVP because they contribute to improve knowledge of the phytocoenosis biodiversity of these biogeographic areas. Indeed, the Mediterranean area is one of the world's major hotspots for plant diversity, where $10 \%$ of the world's higher plants occurs in an area representing only $1.6 \%$ of the earth's surface (Medail \& Quezel 1997). The prominent role played by these areas as reservoirs for plant biodiversity has been emphasized by Myers (1990). The flora of the Mediterranean basin in a broader sense includes more than 25,000 species of flowering plants, making it the third richest in the world. More than 30 Mediterranean plants are considered to have become extinct during the last century. It has been estimated that nearly $25 \%$ of the Mediterranean flora may be threatened in the decades to come (Leon \& al. 1985). In the Mediterranean biogeographical region (northern part of the basin), the number of species for a certain area (areal richness) may be twice the number found in corresponding areas in northern Europe (Ozenda 1994).

The Mediterranean and the Temperate macrobioclimates, sensu Rivas-Martínez \& al. (2011), occupy about $14 \%$ and $53 \%$ of the European territory, respectively. In Italy, the Mediterranean and the Temperate macrobioclimates occupy $43 \%$ and $57 \%$ of the territory; $40 \%$ of the Temperate macrobioclimate (equivalent to $25 \%$ of the national territory) belongs to the sub-Mediterranean variant (Fig. 1 and Table 1). Therefore, the subMediterranean variant of the Temperate macrobioclimate extends for a large portion of the Italian territory and shows a high variability in bioclimatic terms particularly with regard to summer drought. This variability is classified into different submediterraneity levels (Rivas-Martínez \& al. 2011) (Table 2 and Fig. 1).

The Italian Adriatic sectors of the sub-Mediterranean variant have different bioclimatic characteristics as compared with the Tyrrhenian ones due to their geographical position: 


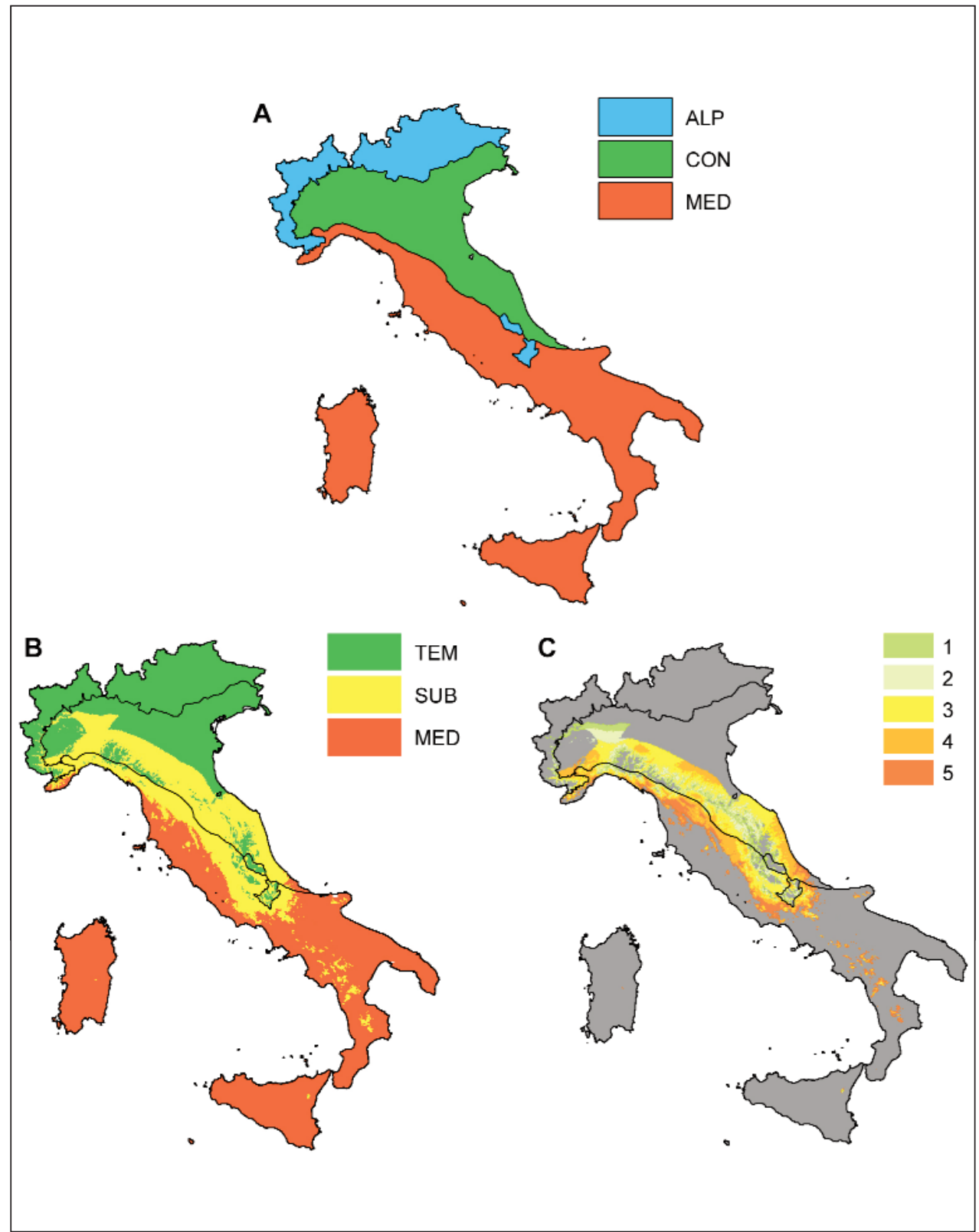

Fig. 1. A) Map of the EU biogeographical regions. ALP-Alpine; CON-Continental; MEDMediterranean. B) Map of Macrobioclimates of Italy. TEM-Temperate; SUB-Temperate subMediterranean variant; MED-Mediterranean. The black line represents the boundaries of the EU biogeographical regions. C) Map of the sub-Mediterranean levels of Italy.1 - Extremely weak; 2 - Highly weak; 3 - Weak; 4 - Strong; 5 - Highly strong. The black line represents the boundaries of the EU biogeographical regions. The bioclimatic data are sensu Rivas-Martínez \& al. (2011) derived from Pesaresi \& al. (2014). 
Table 1. Pivot table of the EU biogeographical regions and macrobioclimates of Italy. Columns are the macrobioclimate regions sensu Rivas-Martínez \& al. (2011) derived from the bioclimatic map of Italy (Pesaresi \& al. 2014). Rows are EU biogeographical regions. Values are percentage of the whole Italian territory. Temp - Temperate; Submedit - Temperate sub-Mediterranean variant; Medit Mediterranean; Alp - Alpine; Cont - Continental; Medit -Mediterranean.

\begin{tabular}{|c|c|c|c|}
\hline & Temp & Submedit & Medit \\
\hline Alp & 0.17 & 0.01 & 0.00 \\
\hline Cont & 0.16 & 0.13 & 0.00 \\
\hline Medit & 0.00 & 0.10 & 0.43 \\
\hline Total & 0.33 & 0.24 & 0.43 \\
\hline
\end{tabular}

lower annual rainfall, less summer drought and thus lower sub-Mediterraneity levels, colder winters, and a slightly higher continentality.

Furthermore, the new vegetation syntaxonomy of the Italian peninsula (IVP) establishes a better relationship with the coarse biogeographic classification proposed by the EU.

In Italy, according to the European biogeographic classification, Alpine, Continental and Mediterranean biogeographical regions extend for $18 \%, 29 \%$, and $53 \%$ of the territory, respectively. The comparison with the bioclimatic map of Italy shows that about $45 \%$ of the Continental biogeographic region and 19\% of the Mediterranean biogeographic region fall within the Temperate macrobioclimate sub-Mediterranean variant (Table 1). Consequently, the attribution of a habitat to a certain biogeographic region made on the basis of the Interpretation Manual of European Union Habitats - EUR28 is more administrative than scientific and, therefore, not fully comprehensive and adequate.

Table 2. Sub-Mediterraneity levels sensu Rivas-Martínez \& al. (2011) of Italy. The first column shows the occurrence of the sub-Mediterraneity level in percentage relative to the entire territory. The second column is the occurrence of the sub-Mediterraneity level in percentage relative to the subMediterranean variant of the Temperate macrobioclimate. The data are derived from the bioclimatic map of Italy (Pesaresi \& al. 2014).

\section{Sub-Mediterraneity levels}

$\begin{array}{lll}\text { Extremely weak } & 3 & 12 \\ \text { Highly weak } & 5 & 18 \\ \text { Weak } & 8 & 30 \\ \text { Strong } & 7 & 27 \\ \text { Highly strong } & 3 & 13\end{array}$


The Apennines are defined as a biogeographic crossing area as its flora is made up of a mixture of elements of different origins such as northern Europe, eastern and western species, and relatively few endemic species.

The phytogeographic element known as the Apennine-Balkan element, described by Pezzetta (2010), is also important from a bioclimatic point of view as discussed above. In fact, this element perfectly justifies the relationship between the Apennine territories of the Adriatic and Ionian side with the southern Balkan Peninsula, as proposed with respect to the bioclimatic conditions of the Italian peninsula.

These are the bioclimatic and biogeographical conditions that led over time to establish a significant correlation, in syntaxonomical terms, of many vegetation types, such as forests, meadows, montane chamaephytic formations as well as coastal communities and shrublands, to the eastern system of classification (Cutini \& al. 1996; Blasi \& al. 2004; Košir \& al. 2008; Allegrezza \& Biondi 2011; Biondi \& Galdenzi 2012; Košir \& al. 2013). Therefore, a major change occurred over time in the syntaxonomy of the Italian vegetation, which was previously almost exclusively driven by the central and western Europe syntaxonomical classifications, except for the north-easternmost areas (Poldini 1989). In this way, the Italian peninsula, because of the different biogeographical regions that it encloses, plays the role of biogeographical joint. In fact, the geographical position that it occupies places Italy at the center of the Mediterranean.

About one-third of the Mediterranean biogeographic regions is used for agriculture, including grasslands. Forests and other wooded lands, scrub and heathlands with dwarf shrubs together dominate more than half of the region. Abandonment of agricultural practices and fires lead spontaneously to scrub formations and from that to secondary forests. In the Mediterranean region of EU-27, 425 species and sub-species (Annex II of Habitats Directive) and 147 habitat types are of Community importance (Annex I Habitats Directive). Of these, 37 are EU-27 priority habitat types, and 26 types occur only in the Mediterranean region (European Environment Agency, http://www.eea.europa.eu).

According to Habitats Directive (92/43/CEE) habitats are defined through syntaxa, so allowing an easy recognition of them. Often, however, Mediterranean habitats are not as clearly recognizable as the Continental and Atlantic ones because of the lack of clear syntaxonomic references. This is a very important issue because the phytosociological science, with its concepts and methods, allows the interpretation of all habitat features, beyond their mere identification. In fact, phytosociology helps to understand habitat transformations linking them to a dynamic landscape view of territories in their own biogeographic regions. Human activities have played a crucial role on the vegetational successions that phytosociologists have long since understood and used to direct conservation measures and to compile the impact assessment requested by Habitats Directive. Phytosociological and syntaxonomic knowledge also plays an important role in the projects promoted by the European Commission (LIFE projects, Horizon 2020, etc.) concerning the reintroduction and reinforcement of threatened species and, specially, for restoration and recovery of habitats assessed as unsatisfactory. 


\section{Guiding concepts in the Prodrome implementation}

The IVP, coherent with the concepts partially explained in the introduction of this paper, aims to combine the current needs of a syntaxonomic classification that should be:

1. - consistent with the physiognomic and structural uniformity of plant communities classified in hierarchical levels;

2. - consistent with the ecology, because plant community structure and function, like that of species, are strictly linked;

3. - consistent with the biogeographical context where plant communities occur. In fact, just as species vary among different individual biogeographic areas, vegetation typologies also vary with significant effects on the hierarchical levels of the plant communities;

4. - most appropriate, in hierarchical terms, to express the high phytocoenotic biodiversity of Mediterranean and sub-Mediterranean plant communities. This can be achieved, for example, by raising to the order level a number of alliances or creating new suborders and suballiances, so as to obtain a more articulated and, therefore, more precise and easily usable classification;

5. - most appropriate to represent the dynamic processes, no longer considered to be marginal aspects in the study of plant communities. In fact, they are fundamental in the transformation of the plant landscape because they promote a classification that pays closer attention to the ecology of vegetation edges (Trifolio medii-Geranietea sanguinei) and forest mantles (Rhamno catharticae-Prunetea spinosae) playing a key role in the dynamics of the plant landscape;

6. - complying with vegetation classes that are already universally accepted even if they do not always respect the rules of the International Code of Phytosociological Nomenclature (ICPN). It is, therefore, necessary that in the same code, under review by a competent committee, an article be included on nomina conservanda, so that the phytosociological classifications of different countries can match, at least for the highest hierarchical levels (see also Willner \& al. 2015);

7. - more easily accessible even to non-specialists, e.g., by inserting definitions of each syntaxonomical rank, so that syntaxa and their practical applications can be better understood;

8. - more appropriately applicable. For example, via recognition and classification of habitats sensu Directive 92/43/EEC and of the transformations of the same habitats in relation to global change and thus to their preservation.

Some significant examples are reported below, showing how syntaxonomic conceptions of some syntaxa can be improved by applying the above-mentioned rules. These examples are representative of the overall knowledge gained through years of research carried out by a group of phytosociologists, including the authors of this article.

\section{Materials and methods}

The manuscript relies on previously published articles concerning the IVP, especially those describing new Mediterranean and sub-Mediterranean syntaxa (Biondi \& al. 
2014b). For the bioclimatic references, the classification of Rivas-Martínez \& al. (2011) and the bioclimatic map of Italy (Pesaresi \& al. 2014) were followed. For the coding of new syntaxa, the ICPN was consulted (Weber \& al. 2000). Regarding the taxonomic nomenclature, we followed Pignatti (1982), Conti \& al. (2005) and Conti \& al. (2007) and the following websites: http://www.anarchive.it and http://www. theplantlist.org. Finally, the new syntaxa proposed here have been surveyed following the phytosociological method (Braun-Blanquet 1928; Braun-Blanquet 1932; Tüxen 1979; Géhu \& Rivas-Martínez 1981; Theurillat 1992; Rivas-Martínez 2005; Géhu 2006; Biondi 2011; Blasi \& Frondoni 2011; Pott 2011).

\section{Coastal vegetation}

The coastal vegetation is the one most exposed to the effects of climate change due to the sea level rise worldwide, particularly evident in the Mediterranean Sea and, even more, in the Adriatic Sea because of its small size and shallow waters in the northern part. The flora of the Mediterranean dunes is essentially made up of endemic species and subspecies, which in turn are distributed in different areas of the regions belonging to the Mediterranean macro-region. As found in many parts of the world, the Mediterranean dunes perform multiple functions simultaneously, such as coastal defense, and protection from erosion resulting in stabilization of the dune system. Human activities supported are: reforestation, agriculture, tourism and urbanization, recreation, information, and education (van der Meulen \& Salman 1996).

The decline in Mediterranean dunes has been severe: it is estimated that since 1900 more than $70 \%$ of them has been lost. Most of the former dune areas has been used for urbanization, not least for tourism. Thus, only few areas remain untouched.

Dunes are the exclusive habitat of many plant and animal species and many dune species are endemic. Animal life (snails, arthropods, insects, lizards, tortoises, rabbits) is often not very visible. An accurate and in-depth knowledge of the vegetation and its dynamic aspects at the level of dune systems and halophilous and hyperhalophilous habitats is, therefore, extremely important for the reconstruction of the protective systems of the coastal micro-habitats recognized by the Habitats Directive. They are, in fact, extremely threatened.

Seventy percent of the Italian coasts are represented by low, sedimentary, sandy or gravelly coasts. They extend over a length of 3,270 km and an area of $120 \mathrm{~km}^{2}$ and are particularly vulnerable to the effects of global warming. A model based on predicted climate change over this broad area (Prisco \& al. 2013), despite the limitations of the simulation, indicates that, without proper management, the habitats of the fixed and mobile dunes may even disappear in the short term. These changes may have important implications for biodiversity conservation, as well as for long-term predictions of the effects of global climate change (Heijmans \& al. 2008).

In Italy, a large number of coastal plant communities still occur resulting in a high biodiversity, despite the strong alteration that habitats have suffered from the negative factors indicated. Therefore, it is necessary to carry out a recovery strategy that would allow the preservation of ecosystems and thus the improvement of natural areas of Italian coasts 
(Biondi \& Zivkovic 2014). For this purpose, careful management of these habitats is needed. It is certainly a priority for Italy, as shown by the diachronic analyses carried out in some Italian coastal areas (Brachetti \& Conti 2014; Del Vecchio \& al. 2015).

\section{Coastal dune vegetation}

The first complete syntaxonomic study of the Italian sedimentary coasts and retrodunal salt environments was the result of a phytosociological excursion led by J.-M. Géhu and J. Géhu-Franck in 1982 with a group of Italian and Spanish researchers. In the publication of the relevés collected during that excursion, a rather exhaustive syntaxonomic scheme was proposed (Géhu \& al. 1984).

Previously, studies on this part of the Italian territory had a more regional or strictly local character. Amongst these, a study characterised by greater precision and originality for its times was performed by Pignatti $(1952,1953)$ on the eastern plain of the Veneto Region. Further investigations on this area allowed to adjust some syntaxonomical aspects and take a census of the conservation status of the vegetation growing in this extremely important sector of the Mediterranean basin (Buffa \& al. 2007; Sburlino \& al. 2013).

The syntaxonomic scheme concerning plant communities growing on the Italian side of the Adriatic basin has been, since then, used and updated by Géhu \& Biondi (1996) and later by Biondi (1999) with a review of all the vegetation of the Italian sandy coasts and cliffs. Again, Biondi (2007) expanded the vision to the entire Mediterranean basin and proposed successional schemes of sandy coasts and cliffs including new important syntaxa. These schemes have recently been followed and modified by Pirone \& al. (2014) in a review of the Ionian and Adriatic coastal vegetation, whereas Acosta \& al. (2009) and Stanisci \& al. (2014) have dealt with the monitoring of the dune coastal habitats.

In the IVP, the vegetation dominated by perennial grasses growing on the coastal sandy dunes of the Mediterranean areas was recently referred to the class Euphorbio paraliaeAmmophiletea australis Géhu \& Rivas-Martínez in Rivas-Martínez \& al. 2011. This class replaces the class Ammmophiletea Br.-B1. \& Tüxen ex Westhoff, Dijk \& Passchier 1946 as it groups the vegetation of Atlantic and Mediterranean dunes in a single class (Biondi \& Galdenzi 2014). The correct definition of the class is: "Psammophilous perennial vegetation from coastal sandy and fine-pebbly dunes with a Mediterranean, Atlantic, Macaronesian and north African coastal distribution, which is important in the dune construction and stabilisation processes" (errata corrige of the article by Biondi \& Galdenzi (2014) published in June 2015 in the journal Plant Sociology vol. 52 (1), p. 64).

The separation between the Atlantic and the Mediterranean and thermo-Atlantic dune vegetation is performed at the level of order by recognizing the order Elymetalia arenarii Br.-Bl. \& Tüxen 1943 for the Atlantic north-European coasts and the order Ammophiletalia australis Br.-Bl. 1933 for the Mediterranean and thermo-Atlantic ones. In this way, if the role of basic rank for grouping phytocoenoses according to the biogeographical macro-units Region and Subregion (Rivas-Martínez 2007) is assigned to the order, the alliance can represent the ecologically-based hierarchical level, while the suballiance can represent the rank 
in which the biogeographical and ecological features are better described (Biondi \& Galdenzi 2014). With regard to the Mediterranean dune vegetation, order Ammophiletalia australis includes three alliances that group phytocoenoses making up the geosigmeta of the dune landscape: Ammophilion australis for the mobile dune formations, Agropyrion juncei (R. Tüxen in Br.-B1. \& R. Tüxen) Géhu, Rivas-Martínez \& R. Tüxen 1972 in Géhu \& al. 1974 for the embryonic dune formations, and Elymion gigantei Morariu 1957 for communities that colonize Pontic dunes. This classification, defined at the level of alliance, has been recognized since a long time and is, therefore, maintained (Géhu \& al. 1984; Géhu 1986; Géhu \& Franck 1988; Géhu \& al. 1994; Géhu \& Biondi 1996).

As part of the alliance Ammophilion australis, suballiance Ammophilenion australis Br.B1. 1933 is recognized. It describes the psammophilous perennial, herbaceous communities that colonize the mobile dunes in Mediterranean and European Thermo-Atlantic littoral areas. As far as the alliance Agropyrion juncei is concerned, five suballiances are recognized: (i) Sporobolenion arenarii Géhu ex Biondi \& Galdenzi 2014, which includes the first perennial vegetation of the first part of the embryonic dune, directly reachable by seawater; (ii) Elymo farcti-Otanthenion maritimi Biondi \& Galdenzi 2014, which groups the vegetation of the inner part of the embryonic dune characterised by reduced mobility of the sandy substrate; (iii) Echinophoro spinosae-Elymenion farcti Biondi \& Galdenzi 2014, which groups the communities of the central-eastern Mediterranean up to Greece; (iv) Agropyrenion farcti Rivas-Martínez, Costa, Castroviejo \& Valdés 1980 of the communities of the western Mediterranean; (v) Sileno succulentae-Elymenion farcti Biondi \& Galdenzi 2014, which includes the communities of the Mediterranean coast of North Africa.

The full syntaxonomical scheme for this vegetation type is found on the website (http://www.prodromo-vegetazione-italia.org/).

\section{Halophytic vegetation of coastal wetlands}

Wetlands are directly interconnected to sandy coastal environments and represent highly threatened habitats in the European part of the Mediterranean basin. These habitats are linked to those sandy and gravel coastal ones where topographic variations are sometimes very limiting. Erosion in a dune system may favour the establishment of salt marshes provided that artificial barriers have not been created to safeguard beaches. Thus, the fate of coastal wetlands is perhaps more intrinsically linked to the complex economic and sociological decisions determining the creation of coastal infrastructure rather than to the effect of climate change itself (Kirwan \& Megonigal 2013).

Studies carried out in different parts of the Mediterranean region have dealt not only with the perennial hyperhalophilous vegetation but also with the annual one corresponding to the 1420 "Mediterranean and thermo-Atlantic halophilous schrubs (Sarcocornietea fruticosae)" and 1310 "Salicornia and other annuals colonizing mud and sand" habitats. The IVP innovations mostly concern the vegetation of the genus Halocnemum, for which, in recent years, many taxonomic and ecological aspects and, therefore, phytosociological and syntaxonomical issues, have been clarified. 


\section{The vegetation of Halocnemum: taxonomy, ecology, phytosociology and syntaxonomy}

In the IVP, this vegetation has been assigned to the Sarcocornietea fruticosae class which includes the perennial halophilous vegetation within which the order Halocnemetalia cruciati Biondi, Casavecchia, Estrelles \& Soriano 2013, defined as "Woody and semi-woody, succulent, hyper-halophilous vegetation that spreads along the Mediterranean coasts, even as far as the Middle East, and marginally found in the Eurasian inlands" (Biondi \& al. 2013), has been included.

\section{Taxonomic aspects and distribution in Italy}

The proposal of this new order is a part of the research conducted on the taxonomy of the genus Halocnemum based on the fact that, in the Mediterranean basin and in Europe, authors of the phytosociological studies have referred in the past to a single species: Halocnemum strobilaceum (Pallas) M. Bieb. (Biondi \& al. 2013). Nevertheless, the fact is that two morphotypes, that have been identified as "nano-phanerophytic" and "chamaephytic morphotype" (Biondi \& Casavecchia 2010), are clearly evident. DNA analyses allow us to hypothesize that these two morphotypes may correspond to different taxa (Papini \& al. 2004) as acknowledged in taxonomic terms. Indeed, the "nano-phanerophytic" morphotype can be identified as Halocnemum cruciatum (Forssk.) Tod. (Syn: H. drepanensis Lojacono, Salicornia drepanensis Tin., Salicornia cruciata Forssk., H. strobilaceum var. cruciatum Moq., H. yurdakulolii Yaprak \& Kadereit) (Bacchetta \& al. 2012; Biondi \& al. 2013). This species grows exclusively in the warmest European Mediterranean central-western area (eastern Spain and Tyrrhenian Italy), as well as in North Africa, the Sinai Peninsula, and the Middle East. In Italy, both species of Halocnemum can be found, H. cruciatum grows in southern Sardinia in the Santa Gilla lagoon, near Cagliari (Mossa \& Biondi 1992) and on the island of Sant'Antioco (De Marco $\&$ al. 1980), and in western Sicily in the salt marshes of Trapani (Brullo \& Di Martino 1974). In the case of $H$. strobilaceum, two populations have been found in the Italian peninsula, one in the northern Adriatic coast, in the State Nature Reserve of Sacca di Bellocchio, close to Ravenna and in the Valli di Comacchio (Corbetta 1976; Cortichelli \& al. 1999; Piccoli \& al. 1999). The other is located on the northern Tyrrhenian coast in the Maremma Regional Park (Arrigoni \& al. 1985; Biondi \& al. 2013). Recently, a new locality of $H$. strobilaceum, situated in the southern part of the Italian Adriatic basin, at the mouth of River Carapelle in northern Apulia (Sciandrello \& Tomaselli 2014), has been described. However, by observing the photos appearing in the publication it seems that it could be attributed to $H$. cruciatum. In fact, when this species grows in predominantly sandy soils with low clay content, it does not reach large dimensions. It is still recognizable by its branches that stem directly from the soil, and, in some cases, as can be observed in Tunisia, it can create microdunes in areas near the sea where sea water reaches them frequently. The two localities of $H$. strobilaceum in peninsular Italy are in the area of transition between the Temperate and the Mediterranean macrobioclimatic conditions, rather than in the sub-Mediterranean variant of the Temperate macrobioclimate. Indeed, the phenotype having a smaller size occurs in ecological and bioclimatic conditions that are more similar to those of continental Europe (Biondi \& al. 2013). 


\section{Vegetation and syntaxonomy}

The syntaxonomic interpretation of hyperhalophilous woody or semi-woody vegetation with Halocnemum M. Bieb. along the coasts of the Mediterranean basin has been described by Biondi and co-workers (2013, 2014b). A brief summary (Fig. 2) and the syntaxonomic scheme are presented below.

SARCOCORNIETEA FRUTICOSAE Br.-Bl. and Tüxen ex A. and O. Bolós, 1950 em. Biondi, Casavecchia, Estrelles \& Soriano 2013

SARCOCORNIETALIA FRUTICOSAE Braun-Blanq. 1933 nom. mut. prop. RivasMartínez \& al. 2002

HALOCNEMETALIA CRUCIATI Biondi, Casavecchia, Estrelles \& Soriano 2013

Halocnemion cruciati Biondi, Casavecchia, Estrelles \& Soriano 2013

Communities with a European and African Mediterranean littoral distribution, including the Middle East with penetrations into the Sinai Peninsula and growing in the semi-arid to hyperarid Mediterranean.

Halocnemion strobilacei Biondi, Casavecchia, Estrelles \& Soriano 2013

Communities occurring along European coasts of the Mediterranean Basin and growing in

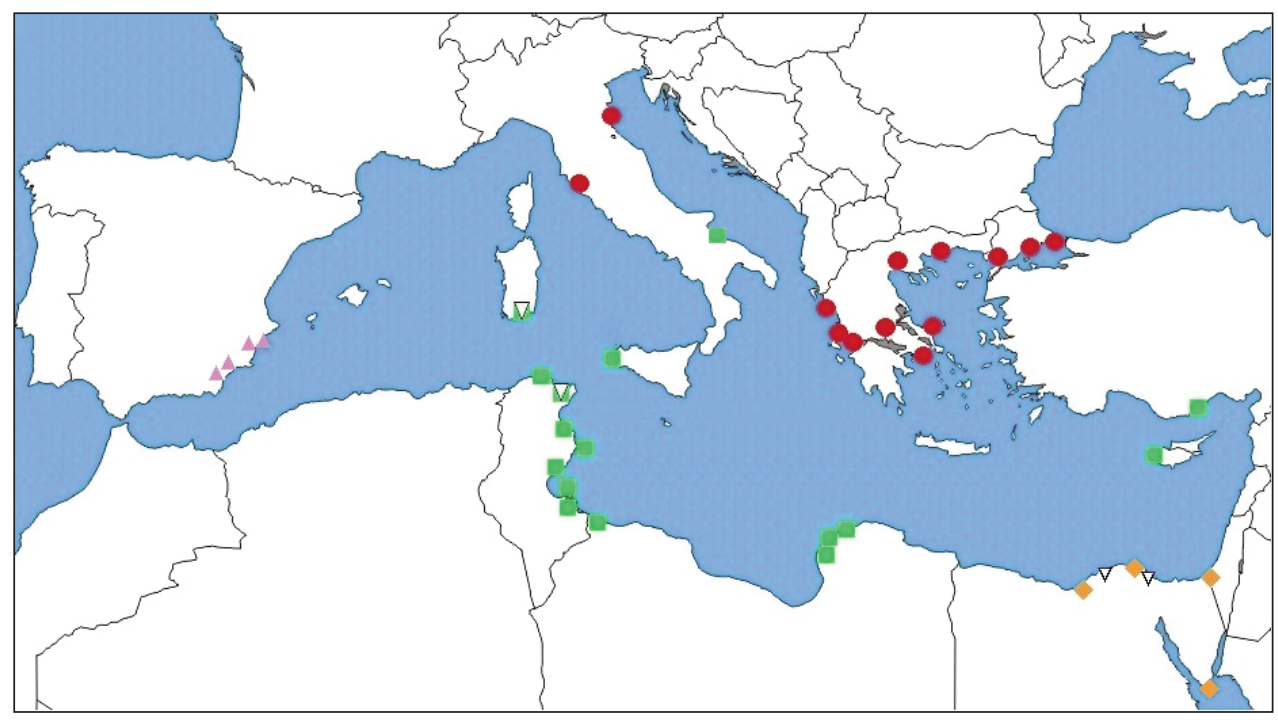

Fig. 2. Distribution of plant communities with Halocnemum strobilaceum and H. cruciatum along the coasts of the Mediterranean basin. Frankenio corymbosae-Halocnemetum cruciati; Arthrocnemo macrostachyi-Halocnemetum cruciati; Arthrocnemo glauciHalocnemetum strobilace $; \nabla$ Halocnemo cruciati-Sarcocornietum fruticosae, Zygophyllo albi-Halocnemetum cruciati (modified from Biondi \& al. 2013). 
Temperate sub-Mediterranean macrobioclimate or Mesomediterranean thermotype of Mediterranean macrobioclimate (Biondi \& al. 2013).

The complete syntaxonomic scheme for Italy is present on the IBS website: http://www.prodromo-vegetazione-italia.org.

According to the results of the ecological analyses on bioclimatic conditions and soil features carried out on the two populations: Sacca di Bellocchio (Ravenna, Italy) for H. strobilaceum and El Hondo (Crevillente, Spain) for H. cruciatum, the two species of the genus Halocnemum grow in completely different environments. The first grows in the subMediterranean variant of the Temperate macrobioclimate, with a mean annual temperature of $13.7 \mathrm{C}^{\circ}$ and a mean annual rainfall of $584.2 \mathrm{~mm}$ in the Mesotemperate upper dry (Andreucci $\&$ al. 2000) and the second in the Mediterranean xeric-oceanic climate (Thermo-Mediterranean semiarid), with a mean annual temperature of $18 \mathrm{C}^{\circ}$ and an average annual precipitation of 286 $\mathrm{mm}$ (Estrelles \& al. 2015). This study also provided information on the germination behaviour related to divergent environmental conditions, demonstrating that water availability affects the germination response of Halocnemum seeds. Germination strategies of the two populations with contrasted rainfall regimes and soil aridity, were evaluated in relation to soil salinity and features, especially texture and conductivity. The H. cruciatum population (El Hondo) and that of H. strobilaceum (Sacca di Bellocchio) grow on sandy loam to clay loam soils and on clay soils, respectively. In the case of the H. strobilaceum population, waterlogging is much more favoured in comparison to the other population. These soil features, combined to a decrease in the mean annual temperature and greater annual rainfall, result in a longer flooding period and lower salinity in the dry period in Sacca di Bellocchio (Andreucci \& al. 1999) as compared to El Hondo (Fig. 3). These ecological data are of great help in order to spatialize species and communities in the Mediterranean region and to plan how to reinforce them or recreate their environments where they have been destroyed (Estrelles \& al. 2015).

\section{Ecotone vegetation}

Historical data related to the dynamic processes occurring in vegetation is one of the most important chapters of phytosociology in the more than 100 years since its foundation (Biondi 2011). Phytosociological studies in ecotonal areas between forest formations and the herbaceous meadows and pastures are particularly important for the understanding of the dynamic processes occurring in this area for the shrub vegetation class RhamnoPrunetea and the herbaceous vegetation class Trifolio-Geranietea (Tüxen 1979; Géhu 1979; Géhu \& Rivas-Martínez 1981; Géhu 1988; Theurillat 1992; Rivas-Martínez 2005; Biondi \& al. 2006; Biondi 2011). The recognition of shrubs communities surrounding the forest and of those that are projected outside of these when the grasslands are no longer used in the agronomic or pastoral sense was the first major step forward in the understanding of natural phenomena triggered independently in the vegetation. Long-term observations conducted in the ecotonal area have also led to the discovery that along the forest margin, where shade is produced by the tree canopy, a sciaphilous vegetation develops, consisting of nemoral herbaceous species that tend to emerge naturally in this area. In the illuminated part, that of the grassland, a similar process takes place after abandonment, leading to concentration of heliophilous species in the same ecotonal area, which is con- 


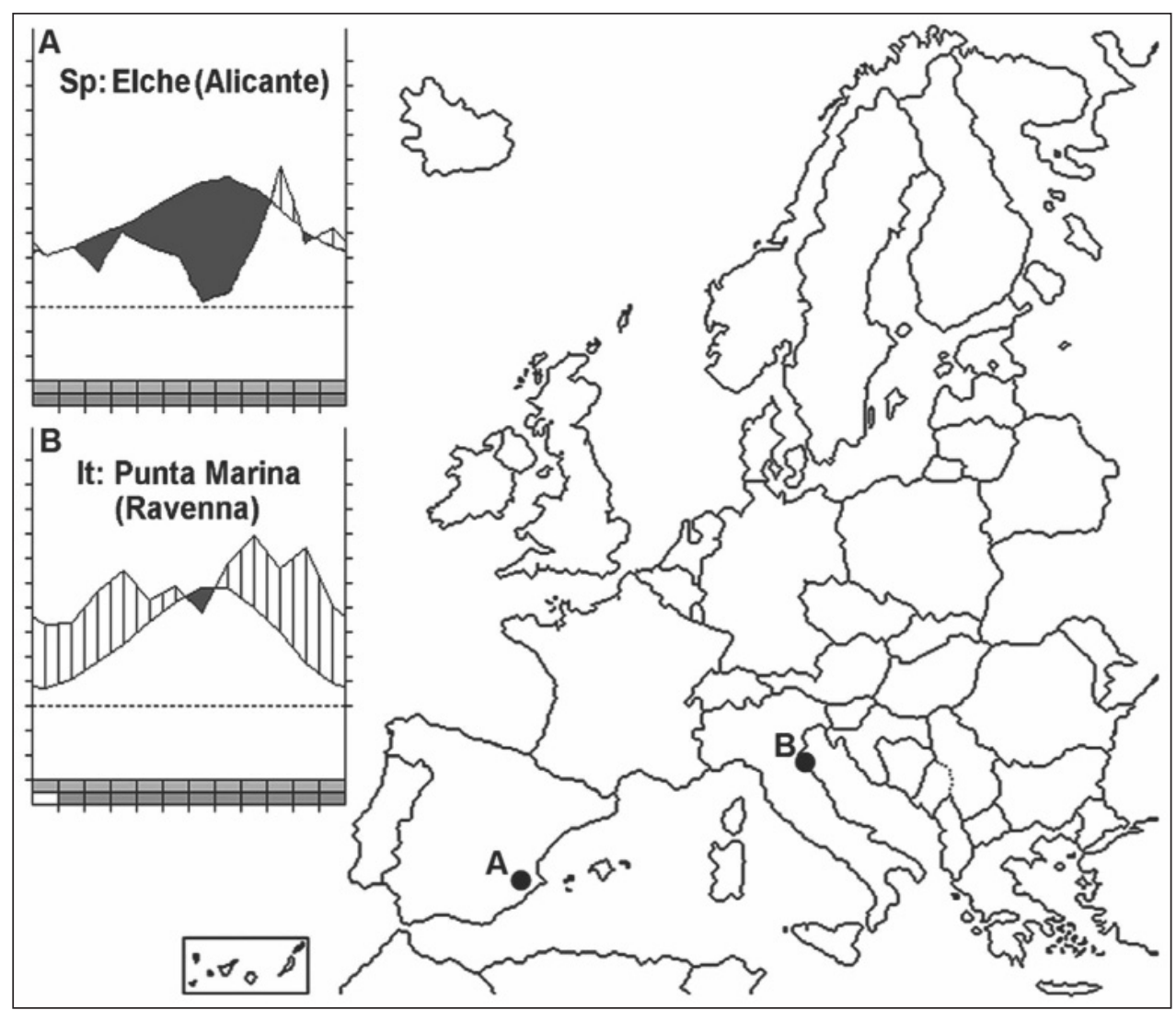

Fig. 3. Bioclimatic diagrams from nearby thermopluvial stations: El Hondo, Alicante, Spain (A) and Sacca di Bellocchio, Ravenna, Italy (B) (from Estrelles \& al. 2015).

tinuous with the sciaphilous part. Sciaphilous and heliophilous vegetation edges are, therefore, the elements that define a dynamic process in which research, currently very active, helps to better define the dynamic processes. In the IVP, with the insertion of the Asphodeletalia macrocarpi order within the class Trifolio-Geranietea, these dynamic processes, such as those concerning the sciaphilous edges and mantles of vegetation, have been given greater attention. All these aspects contribute to enrich and refine the field of synphytosociology in Italy, according to the concepts of syntaxonomy (Bouzille \& De Foucault 1988; Biondi \& al. 2001; Dengler \& al. 2003; Vagge \& Biondi 2004; Čarni 2005; Mucina \& al. 2009; Biondi \& al. 2014a; Biondi \& al. 2014c; Allegrezza \& al. 2015).

\section{Forest edges}

In the IVP, the new alliance Digitali australis-Trifolion medii has been included in the order Origanetalia vulgaris (Biondi \& al. 2015). It groups communities of the pre-forestal 
mesophilous edges and replaces, in Italy, the alliance Trifolion medii Müller 1962 with a predominant central-European and Alpine distribution. Earlier, the alliance Digitali australis-Helleborion bocconei had been inserted in the IVP. That name certainly better expresses the floristic composition of species that characterise the Apennine sciaphilous edges. In fact, in these types of vegetation, the species and subspecies belonging to the genera Digitalis and Helleborus play an important role, specifically in differentiating edge associations (Biondi \& al. 2014a). Previously, Čarni (2005) had proposed the suballiance Digitali-Trifolienion of the alliance Trifolion medii using the same association typus of the alliance Digitali australis-Helleborion bocconei Biondi, Vagge \& Galdenzi in Biondi \& al. 2014 (Digitali australis-Helleboretum bocconei Biondi \& al. 2001). For this reason, the suballiance Digitali-Trifolienion Čarni 2005 was raised to the rank of alliance (Biondi \& al. 2015) in order to restore the most appropriate syntaxonomic level. The classification proposed by Čarni (2005), in fact, does not appear to be more suitable because the plant communities included in the suballiance Digitali-Trifolienion show a higher diversity than those typical of the alliance Trifolion medii. Table I in Carni (2005) shows that the species that characterise and differentiate the suballiance Digitali-Trifolienion medii form a very different group of stands from that of the alliance Trifolion medii as they are endemic and typical of the floristic contest of the Apennines. Moreover, the ordination and the synoptic table (Fig. 3 and Table II in Carni 2005) highlight the inadequate connection between the Apennine communities and the others being compared (Biondi \& al. 2015).

Several associations described for the Italian vegetation are related to this alliance (Digitali australis-Trifolion medii) and express the diversity of the Apennine populations studied so far (Biondi \& al. 2001; Vagge \& Biondi 2004) and of the eastern ones, belonging to the Balkan area, which show a high affinity.

In the IVP, the alliance Geranio nodosi-Digitalion luteae has also been included. It is defined as a group of communities that occurs in the central-northern Apennine mountains, on the Tyrrhenian side, and on marly arenaceous and Flysch substrates. It occurs in the Temperate macrobioclimate, sub-Mediterranean variant, meso- and supratemperate thermotypes and replaces the alliance Digitali australis-Trifolion medii (Čarni 2005) Biondi, Vagge \& Galdenzi 2015 in Biondi \& al. 2015 on acid soils.

\section{Heliophilous edges}

In the IVP, heliophilous edges have been included, like the sciaphilous ones, in the class Trifolio-Geranietea sanguinei Müller 1962 since they affect not only the forest edge but also the heliophilous edges. To this end, the order Asphodeletalia macrocarpi Biondi \& Allegrezza 2014 in Biondi \& al. 2014, which brings together heliophilous communities that develop in the same altitudinal zone following the abandonment of agricultural and pastoral activities, was added to the order Origanetalia vulgaris Müller 1962 that brings together communities of mesophilic forest edges, growing on mature soils rich in humus. Asphodelus macrocarpus communities, included within syntaxa related to the class Festuco-Brometea and showing a specific, clearly autonomous combination related to different dynamic stages, are to be referred to this order as well (Allegrezza \& al. 2014; Biondi \& al. 2014a; Biondi \& al. 2014c). Based on the critical review of the herbaceous communities dominated by A. macrocarpus in the Apennines (Allegrezza \& al. 2015) and 
assigned by the authors to different syntaxa of the Festuco-Brometea and Nardetea strictae classes, three alliances for the Asphodeletalia macrocarpi order have been recognized: (i) Cyano triumfettii-Asphodelion macrocarpi (all. typus), (ii) Thalictro aquilegiifolii-Asphodelion macrocarpi for the upper supratemperate and lower supratemperate thermotype, respectively of the central Apennines (Allegrezza \& al. 2014; Biondi \& al. 2014a; Allegrezza \& al. 2015), and (iii) Hyperico calabricae-Asphodelion macrocarpi for the southern Apennines (Biondi \& al. 2014c). Finally, with the inclusion of heliophilous edge communities dominated by Brachypodium genuense (Allegrezza \& al. 2014), the order Asphodeletalia macrocarpi has been subdivided into two suborders (Biondi \& al. 2015): Asphodelenalia macrocarpi (subord. typus) and Senecio scopoliiBrachypodienalia genuensis (Luzulo sieberi-Brachypodion genuensis alliance typus). It brings together the communities of heliophilous, mesophilous, and sub-acidophilous to acidophilous edges, dominated by Brachypodium genuense, occurring in the supratemperate thermotype of the Apennines with an optimum in the upper supratemperate thermotype, mainly on calcareous substrata, on sites with a prolonged snow cover. Indications on the environmental characteristics and preferential dynamic relationships for each syntaxon (Allegrezza \& al. 2015; Biondi \& al. 2015) contribute to the definition and clarification of the ecological, biogeographical and landscape ranges of the order Asphodeletalia macrocarpi, thus completing the main landscape units for the centralsouthern Apennines (Blasi 2010; Blasi \& al. 2014).

\section{Shrubland and forest mantle vegetation}

Shrub forest mantle formations and shrublands are very widespread in Mediterranean and sub-Mediterranean territories. In particular, shrublands are long-lasting successional stages in the recolonization dynamics of deforested areas and abandoned grasslands and fields. These continuously changing ecotone communities are rich in biodiversity with pioneer plant formations in the initial stages that are replaced over time by more and more complex and demanding coenoses.

In Italy, research on the mantle vegetation developed faster than research on the vegetation of edges because these communities exhibit much more evident dynamic aspects and are, therefore, more easily interpretable.

The first complete revision of the Italian shrublands of the class Rhamno catharticaePrunetea spinosae Rivas Goday \& Borja ex Tüxen 1962 was carried out by Poldini \& al. (2002) with the inclusion of all the associations and alliances in the order Prunetalia spinosae Tüxen 1952 of the above mentioned class. Actually, both the dendrogram and the ordination achieved by elaborating all the relevés (Poldini \& al. 2002, Fig. 1-2) clearly show a strong separation of the most thermophilous Mediterranean and sub-Mediterranean relevés from the others. At that time, those relevés were classified within the alliance Pruno-Rubion ulmifolii and the suballiance Pruno-Rubenion ulmifolii specific for edapho-meso-hygrophilous aspects. Currently, these syntaxa are included in the order Pyro spinosae-Rubetalia ulmifolii Biondi, Blasi \& Casavecchia in Biondi \& al. 2014, recently described by Biondi \& al. (2014a). This new syntaxon was achieved by raising the hierarchical level of the alliance whose chorological range was too broad to distinguish different vegetation aspects. Within the new order, two new alliances were recognized that refer to distinct floristic and bioclimatic aspects. 
The alliance Pruno spinosae-Rubion ulmifolii O. Bolòs 1954 includes thermophilous shrubs and mantles occurring on wet soils and characterized by the presence of a large contingent of Mediterranean species while the alliance Arundo plinii-Rubion ulmifolii Biondi, Blasi, Casavecchia \& Gasparri 2014 in Biondi \& al. 2014 refers to communities dominated by Rubus ulmifolius that grow on soils - from clay to pelitic, arenaceous and marly-arenaceous - with variable water retention capacity and organic matter content (Biondi \& al. 2014a).

The order Lauro nobilis-Sambucetalia nigrae Biondi, Blasi, Casavecchia, Galdenzi \& Gasparri 2014 in Biondi \& al. 2014, widespread in southern Europe in Mediterranean and Temperate bioclimatic contexts, is particularly abundant in the sub-Mediterranean macrobioclimate. It relates to the nitrophilous micro-forests characterised by Sambucus nigra, that are differentiated by species like Laurus nobilis, Rubus ulmifolius, Rhamnus alaternus, Rubia peregrina subsp. longifolia and Hedera helix. The Sambucus nigra vegetation occurs throughout Europe, from central to Mediterranean regions, in different bioclimatic belts and, consequently, in different ecological conditions and biogeographic areas. For this reason, the alliance Lauro nobilis-Sambucion nigrae Biondi, Blasi, Casavecchia, Galdenzi \& Gasparri 2014 in Biondi \& al. 2014, distributed in sub-Mediterranean and Mediterranean regions, has been identified in Italy. Among the shrublands displaying a strong dynamic capacity in the Mediterranean and south-Mediterranean macrobioclimate, formations of Paliurus spina-christi occupy a significant position. They are particularly frequent in central-eastern Europe, but they also occur in Mediterranean France and in north-eastern Spain. Because of the bioclimatic and biogeographic diversification contexts in which the Paliurus vegetation develops, we consider it useful to include the different Italian communities in different alliances and suballiances. Shrublands dominated by Paliurus spinachristi occurring within the Mediterranean macrobioclimate of the lower mesoMediterranean thermotypic horizon with humid ombrotype are coenoses of recovery on abandoned or burned areas that belong to the reconstitution series of thermophilous evergreen forests and olive groves, sometimes with some deciduous trees. Therefore, they are included in the order Pistacio lentisci-Rhamnetalia alaterni Rivas-Martínez 1975 of the class Quercetea ilicis and in the order Oleo sylvestris-Ceratonion siliquae Br.-Bl. ex Guinochet \& Drouineau 1944.

Compared to the maquis formations that this alliance includes, the Paliurus formations can be distinguished floristically by the higher presence of edaphic humidity. For this reason, the suballiance Oleo sylvestris-Paliurenion Biondi, Casavecchia, Biscotti \& Pesaresi 2014 with an eastern European Mediterranean distribution that groups mesoMediterranean and thermo-Mediterranean copses and scrublands, and is in dynamic successional series with sclerophyllous and evergreen woods of the Adriatic and eastern Ionian coasts, has been described. It is currently known for the Gargano coast (Apulia) and on the south-eastern coast of Sicily (Casavecchia \& al. 2015).

With regard to the order Prunetalia spinosae, Italian alpine and Apennine communities of pre-forest mantles linked to mesophilous woods of temperate bioclimates are included in the alliances Berberidion vulgaris Br.-Bl. 1950, Salici elaeagni-Hippophaeion fluviatilis de Foucault \& Julve 2001, Salici cinereae-Viburnion opuli (Passarge 1985) de Foucault 1991 and Humulo lupuli-Sambucion nigrae de Foucault \& Julve 2001. The first Italian endemic alliance described was Cytision sessilifolii Biondi in Biondi, Allegrezza \& 
Guitian 1988 that was proposed for classifying mantles of Apennine thermo-xerophilous woods. Later, the alliance Berberido aetnensis-Crataegion laciniatae Gianguzzi, Caldarella, Cusimano \& Romano 2011 was described in Sicily.

In the Apennine intramontane territories and for the Friulan Karst areas, where the overall bioclimatic and continental conditions are clearly known, we recognize the presence of the order Paliuretalia spinae-christi Trinajstic 1978, which groups together shrub formations of mixed deciduous and evergreen forests that are the recovery stages of the subMediterranean deciduous and semi-deciduous woods occurring in the eastern Mediterranean area on carbonate substrates. Thus, the distribution range of this order includes both the Italian and Balkan peninsulas.

In this order, the alliance Rhamno saxatilis-Paliurion Biondi, Casavecchia, Biscotti \& Pesaresi 2014 is recognized in Italy. It has a western Adriatic distribution and, sometimes, also occurs in Tyrrhenian inland areas. Currently, the alliance is recognized for Karst areas and in the Apennine intramontane lowlands.

\section{Xerophilous and semi-mesophilous secondary grasslands}

The history of research on xerophilous secondary grasslands reflects the path followed by phytosociological and syntaxonomic knowledge of most of the syntaxa occurring in Italy. In the $1960 \mathrm{~s}$, the leading experts in this field came from central Europe (France, Germany and Austria) and the syntaxonomic classifications they made were used as a reference for the Italian vegetation. Over time, both Spanish and Balkan phytosociological research underwent rapid progress leading to a revision of syntaxonomic classifications by arranging the syntaxa of peninsular and insular Italy in the correct biogeographical and bioclimatic context.

In this historical context, the paper describing the alliance Crepido lacerae-Phleion ambigui, the first alliance for xerophilous secondary grasslands of the Apennines (Biondi \& Blasi 1982), occupies a special place. It includes the communities described in previous studies on dry grasslands (Bruno \& Covarelli 1968; Avena \& Bruno 1975; HruskaDell’Uomo 1976; Avena \& Blasi 1979, 1980; Hruska 1982; Ballelli \& Biondi 1982, Biondi \& Ballelli 1982) (Fig. 4). In fact, the first association of Apennine xerophilous grasslands was described by Volk (1958) with the name Xerobrometum apenninum and included in the alliance Xerobromion (Br.-B1. \& Moor 1938) Moravec in Holub, Heijny, Moravec \& Neuhäusl 1967. The name of this association was later changed (Castelli 1995) into Cleistogeno serotinae-Brometum erecti (Volk 1958) Castelli 1995.

Subsequent research on the Apennine grasslands made a large amount of data available for further elaborations, which then led to the description of the alliance Phleo ambiguiBromion erecti (Biondi \& al. 1995) and allowed to clarify the relationship between xerophytic grasslands and chamaephytic garrigues in those mountains (Biondi \& al. 2005).

In the most recent syntaxonomic revision, the xerophilous and semi-mesophilous secondary grasslands from the supra-Mediterranean to the mesotemperate thermotypes have been included in the order Phleo ambigui-Brometalia erecti Biondi, Allegrezza, Blasi \& Galdenzi in Biondi \& al. 2014 (Biondi \& al. 2014a). In this way, communities whose floristic and phytogeographic autonomy is characterised by a large number of endemic and 


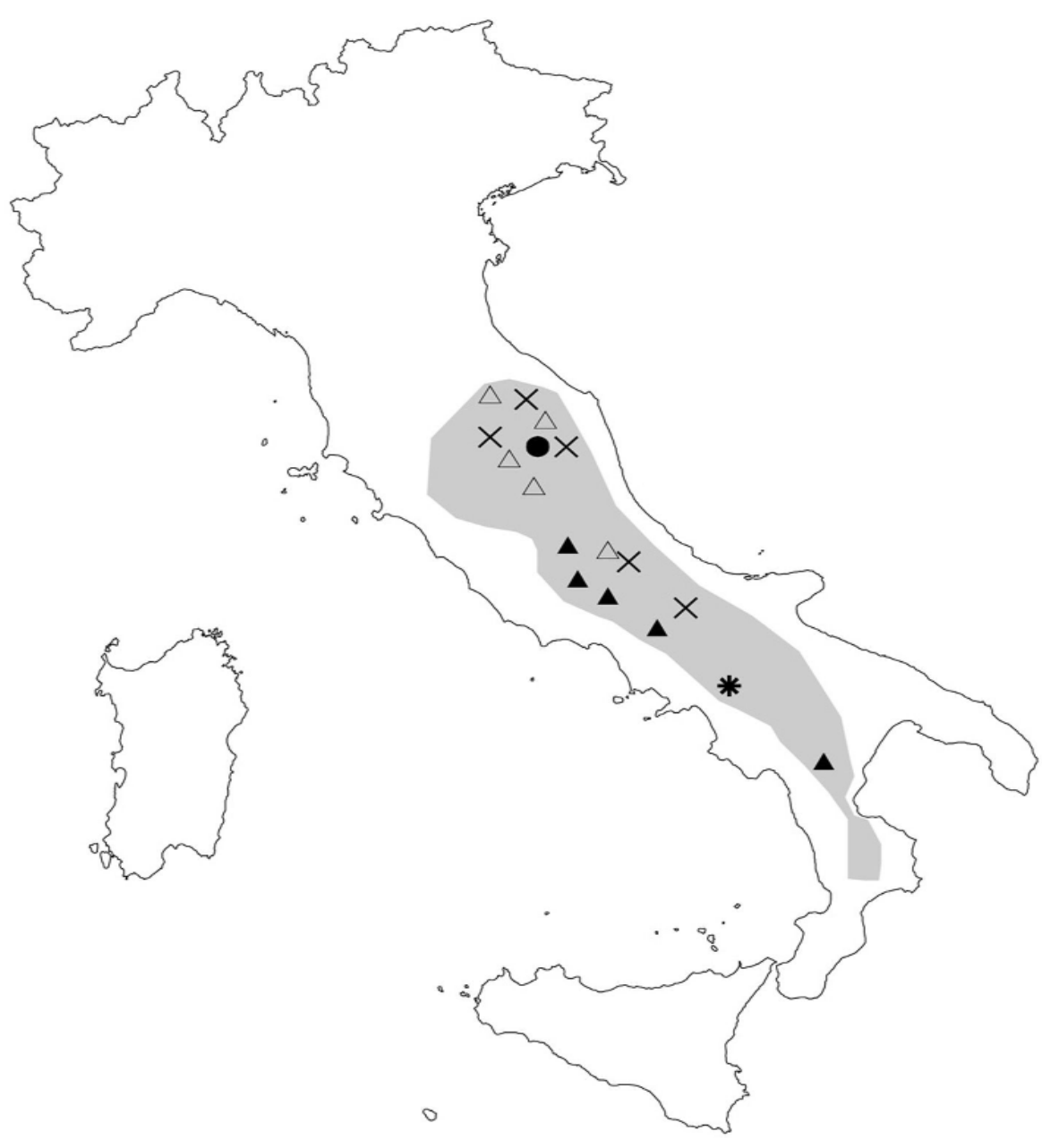

Fig. 4. Distribution range of the alliance Crepido lacerae-Phleion ambigui and its associations derived from Biondi \& Blasi (1982). Gray area, Crepido lacerae-Phleion ambigui; X, Seslerio nitidaeBrometum erecti; *, Pimpinello lithophilae-Astragaletum syrinici; $\Delta$, Asperulo purpureae-Brometum erecti; $\bullet$, Trigonello monspeliacae-Sideritetum syriacae; $\boldsymbol{\Delta}$, Saturejo montanae-Brometum erecti.

sub-endemic taxa typical of secondary Apennine grasslands are grouped together and can be distinguished from conenoses of the order Scorzonero-Chrysopogonetalia.

Previously, in Biondi \& Galdenzi (2012) these grasslands were attributed to the Illyrian order Scorzonero-Chrysopogonetalia. This scheme had been applied for the Friuli Venezia Giulia grasslands (Poldini 1989; Feoli Chiappella \& Poldini 1993) and for the Stipa austroitalica communities growing on the Adriatic slopes of sub-Apennine areas [Apulia, Basilicata, Molise (Forte \& al. 2005; Biondi \& Guerra 2008; Terzi \& al. 2010)]. In these 
studies, the grasslands were attributed to the order Scorzonero-Chrysopogonetalia rather than to the order Brometalia erecti. This attribution was based on the succesional dynamics of the forest vegetation and, of course, on the chorology of the species that make up these grasslands having an eastern range. A similar approach was used for the Appenine grasslands whose flora composition is well characterised by amphi-Adriatic species with an eastern and southeastern range centroid. The scheme proposed in Biondi \& Galdenzi (2012) was a concrete attempt to separate the Appennine grasslands from the central-western European ones belonging to the order Brometalia erecti. Later studies (Di Pietro 2011; Terzi \& Di Pietro 2013; Biondi \& al. 2014a) highlighted the need to propose a new endemic order for the grasslands of the Italian peninsula that could be distinguished both from the central and western order of Brometalia erecti and from the eastern one of ScorzoneroChrysopogonetalia. For these reasons, (Biondi \& al. 2014a) the new order Phleo ambiguiBrometalia erecti (= Euphorbietalia myrsinites Ubaldi 2011 nom. inv. arct. 5) was proposed in which the alliance Phleo ambigui-Bromion erecti Biondi, Ballelli, Allegrezza \& Zuccarello ex Biondi \& Galdenzi 2012 and all its associations were included and considered as typus of the order. Following the conclusions of Terzi and Di Pietro (2013) also Stipa austroitalica communities, belonging to the alliance Hippocrepido glaucae-Stipion austroitalicae Forte \& Terzi in Forte, Perrino \& Terzi 2005, were included in the order Phleo ambigui-Brometalia erecti so that the order Scorzonero-Chrysopogonetalia is confined in north eastern Italy, while the order Brometalia erecti widespreads in the north western part of the Peninsula and in the Apennines where it characterises the more mesophilous pastures belonging to the alliance Bromion erecti Koch 1926. Finally the continental order Festucetalia valesiacae Br.-B1. \& Tüxen ex Br.-B1. 1949 is mainly present in the continental part of the Alps.

As shown in Fig. 5, the boundary among the vegetation of the orders Phleo ambiguiBrometalia erecti, Brometalia erecti Koch in 1926, Scorzonero villosaeChrysopogonetalia grylli Horvatić \& Horvat in Horvatić 1963 and Festucetalia valesiacae Br.-Bl. \& Tüxen ex Br.-Bl. 1949 and their alliances is not always clear.

\section{Conclusions}

The main objective of this article is to highlight how the research efforts necessary to achieve the IVP are based on a logical scheme that can be summarised in eight main points. Implementation of the IVP, besides being, as far as possible, a comprehensive checklist of the vegetation syntaxa of Italy, is also the starting point for a more general process of adjustment of phytosociology 100 years since the foundation of this discipline (Biondi 2011; Pott 2011). Therefore, some significant recently described syntaxa are presented and discussed. The studies carried out in different sectors that led to the decisions proposed in the IVP are described.

It is no coincidence that these syntaxa refer mainly to Mediterranean and subMediterranean areas. The implication of this localisation has been discussed from different points of view, bio-climatic and phytogeographical, and by references to the history of the spread of phytosociological knowledge in Europe and specifically in Italy (Biondi 1996). The result of this process of adaptation of different syntaxa is the current version of the IVP (http://www.anarchive.it and http://www. theplantlist.org). 


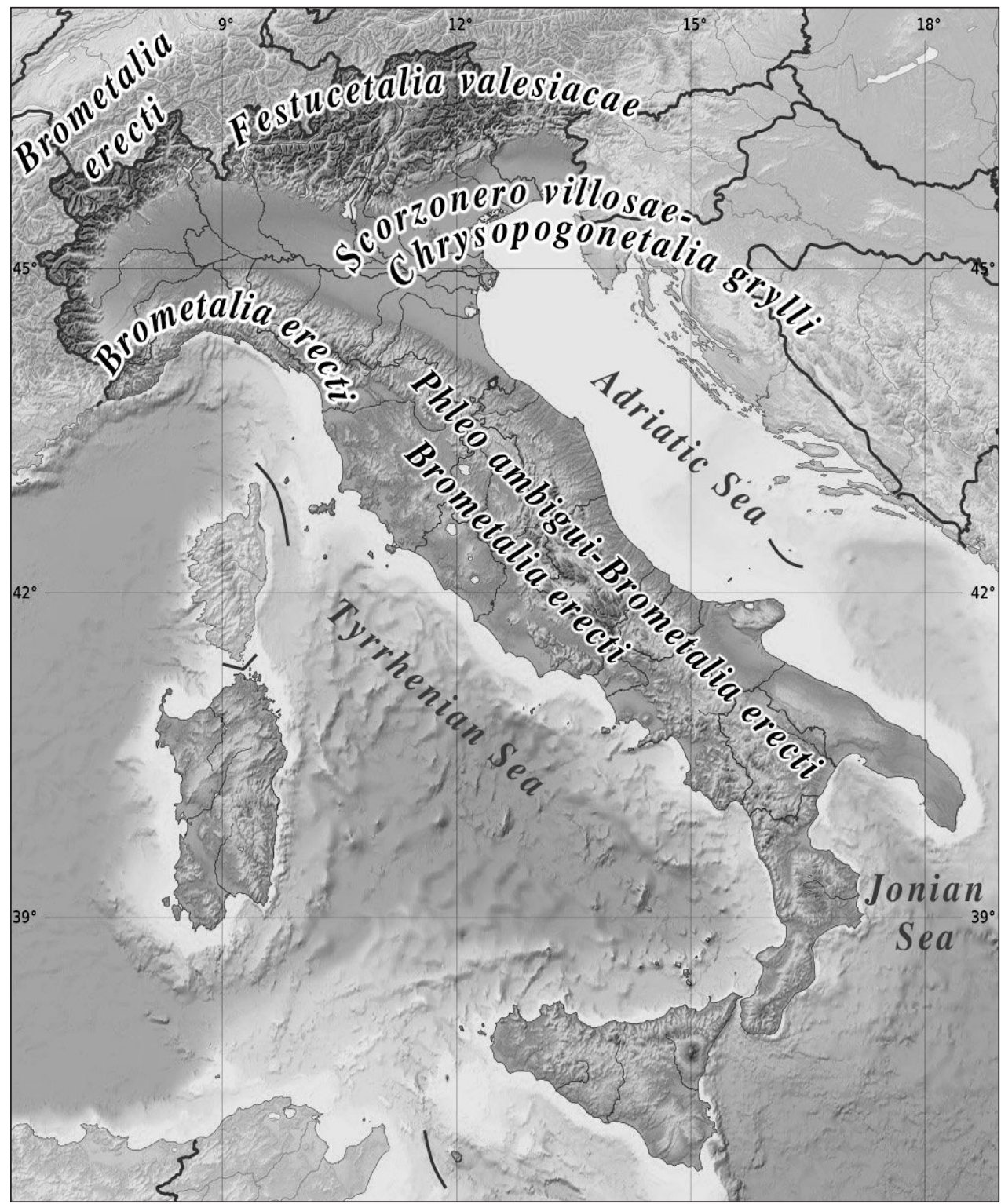

Fig. 5. Distribution range in Italy of the orders Phleo ambigui-Brometalia erecti, Brometalia erecti, Scorzonero villosae-Chrysopogonetalia grylli and Festucetalia valesiacae.

The southern part of Europe has the greatest diversity of flora and phytocoenoses as compared to the rest of the continent. Therefore, the adjustment of national prodromes of southern countries requires a different concept of syntaxonomic classification allowing the full expression of the biodiversity existing from the Iberian Peninsula to Turkey. 
A recent review on the phytosociological classification of floodplain forests in Europe (Douda $\&$ al. 2015) shows as the need to produce a continental scale synthesis can unfortunately underestimate the value of researches made by local specialists and can lead to significant reductions in the knowledge of plant communities biodiversity. This is even more serious if it is compared with the aim clearly expressed by its authors to support the European strategy for biodiversity conservation with this synthesis. Indeed, this strategy aims at better evaluate the local specific features expressed in terms of ecosystem services and green infrastructures. In fact, in that review the high degree of vegetation biodiversity of the southern part of Europe is neglected and the extreme physiognomic simplification it is clear. The review of Douda \& al. (2015) deals with 148 associations whose, after the numerical elaboration only 30 are recognized as real by the authors while 118 are considered as synonyms. Therefore, the result of this drastic synthesis is clear: the basic aspects like the biogeographical value and ecological modelling (the topics of the modern phytosociology) are minimized. Furthermore, the Authors do not take into account the historical progress of phytosociology. In our opinion, these large reviews require a revision also on methods of the syntaxonomic classification, at least on the basis of the eight points mentioned in this manuscript that are the foundations of the IVP. On the contrary, it would be useful to invite phytosociologists to produce national revisions and to use the alliance level as the limit for revision at continental scale. This would avoid the production of syntaxa unrelated to the more general continental pattern, but leaves to local experts the definition of syntaxa strongly correlated with the specific bio-geographical, ecological and syndynamic features of different countries. Only in this way, the ecological and phytogeographical modelling (made at the "association" level) may be useful for the European aims like the evaluating the economic value of the nature services (economic accounting) that by definition must be necessarily incurred with a local detail full syntaxonomic scheme.

\section{References}

Acosta, A. T. R., Carranza, M. L. \& Izzi, C. F. 2009: Are there habitats that contribute best to plant species diversity in coastal dunes? - Biodivers. Conserv. 18(4): 1087-1098. doi: 10.1007/s10531-008-9454-9

Allegrezza, M., Ballelli, S., Ciucci, V., Mentoni, M. \& Pesaresi, S. 2014: The vegetation and the plant landscape of Monte Sassotetto (Sibillini Moun- tains, Central Apennines). - Pl. Sociol. 51: 5987. doi: $10.7338 / \mathrm{pls} 2014511 / 05$

— \& Biondi, E. 2011: Syntaxonomic revision of the Arrhenatherum elatius grasslands of central Italy . - Fitosociologia 48(1): 23-40.

—, - Ballelli, S., Tesei, G. \& Ottaviani, C. 2015: The edge communities of Asphodelus macrocarpus subsp. macrocarpus: the different ecological aspects and a new case study in the central Apennines. - Pl. Sociol. 52(1): 19-40. doi: 10.7338/pls2015521/03

Andreucci, F., Biondi, E., Calandra, R. \& Zuccarello, V. 1999: La vegetazione alofila della Riserva Naturale Sacca di Bellocchio (Adriatico settentrionale). - Pp. 147-172 in: Bono, M., Sburlino, G. \& Zuccarello, V. (eds.), Aspetti ecologici e naturalistici dei sistemi lagunari e costieri. - Venezia.

—, 一, Feoli, E. \& Zuccarello, V. 2000: Modeling environmental responses of plant associations by fuzzy set theory. - Community Ecol. 1(1): 73-80. doi: 10.1556/ComEc.1.2000.1.10

Arrigoni, P. V, Nardi, E. \& Raffaelli, M. 1985: La vegetazione del Parco naturale della Maremma (Toscana). - Firenze. 
Avena, G. \& Blasi, C. 1980: Carta della vegetazione del Massiccio del Monte Velino. Appennino Abruzzese. - P.F. "Promozione della Qual. dell'ambiente", C.N.R., Roma, AQ/1/35 1-18.

— \& - 1979: Saturejo montanae-Brometum erecti ass. nova dei settori pedemontani dell'Appennino calcareo centrale. - Arch. Bot. e Biogeogr. Ital. 55: 34-43.

Avena, G. C. \& Bruno, F. 1975: Lineamenti della vegetazione del massiccio del Pollino (Appennino calabro-lucano). - Not. Fitosociologico 10: 131-158.

Bacchetta, G., Brullo, S., Guarino, G. \& Sciandrello, S. 2012: Studi tassonomici sulle popolazioni italiane di Halocnemum strobilaceum (Amaranthaceae). - Pp. 29-30 in: Peccenini, S., Domina, G. \& Salmeri, C. (eds.), Flora vascolare d'Italia: studi biosistematici, taxa endemici e loci classici . - Firenze.

Ballelli, S. \& Biondi, E. 1982: Carta della vegetazione del Foglio Pergola, 1: 50.000. - P.F. "Promozione della Qualità dell'ambiente" CNR AQ/1/86: 1-33.

Biondi, E. 1996: Origine e sviluppo della fitosociologia in Italia. - Braun-Blanquetia 18: 25-29.

- 1999: Diversità fitocenotica degli ambienti costieri italiani. - Boll. Mus. Civ. Stor. Nat. Venezia 49: 39-105.

- 2007: Thoughts on the ecology and syntaxonomy of some vegetation typologies of the Mediterranean coast. - Fitosociologia 44(1): 3-10.

- 2011: Phytosociology today: Methodological and conceptual evolution. - Pl. Biosyst. 145(sup1.): 19-29. doi: 10.1080/11263504.2011.602748

-, Allegrezza, M., Casavecchia, S., Galdenzi, D., Gasparri, R., Pesaresi, S., Poldini, L., Sburlino, G., Vagge, I. \& Venanzoni, R. 2015: New syntaxonomic contribution to the Vegetation Prodrome of Italy. - Pl. Biosyst. 149(3): 603-615. doi: 10.1080/11263504.2015.1044481

—, 一, —, - —, —, Vagge, I. \& Blasi, C. 2014a: New and validated syntaxa for the checklist of Italian vegetation. - Pl. Biosyst. 148(2): 318-332. doi: 10.1080/11263504.2014.892907

_, _ \& Zuccarello, V. 2005: Syntaxonomic revision of the Apennine grasslands belonging to Brometalia erecti, and an analysis of their relationships with the xerophilous vegetation of Rosmarinetea officinalis (Italy). - Phytocoenologia 35(1): 129-164. doi: 10.1127/0340269X/2005/0035-0129

— \& Ballelli, S. 1982: La végétation du Massif du Catria (Apennin central) avec carte phytosociologique 1:15.000. - Pp. 211-235 in: Pedrotti, F. (ed.), Guide-itinéraire de l'excursion internationale de Phytosociologie en Italie centrale (2-11 juillet 1982) . - Camerino.

—, 一, Allegrezza, M. \& Zuccarello, V. 1995: La vegetazione dell'ordine Brometalia erecti Br.-B1. 1936 nell'Appennino (Italia). - Fitosociologia 30: 3-45.

— \& Blasi, C. 1982: Crepido lacerae-Phleion ambigui nouvelle alliance pour les paturages arides a Bromus erectus de l'Apennin calcaire central et meridional. - Doc. Phytosociologiques 7: 435-442.

-, 一, Allegrezza, M., Anzellotti, I., Azzella, M. M., Carli, E., Casavecchia, S., Copiz, R., Del Vico, E., Facioni, L., Galdenzi, D., Gasparri, R., Lasen, C., Pesaresi, S., Poldini, L., Sburlino, G., Taffetani, F., Vagge, I., Zitti, S. \& Zivkovic, L. 2014b: Plant communities of Italy: The Vegetation Prodrome. - Pl. Biosyst. 148(4): 728-814. doi: 10.1080/11263504.2014.948527

-, Čarni, A., Vagge, I., Taffetani, F. \& Ballelli, S. 2001: The vegetation of the Trifolio mediiGeranietea sanguinei Miller 1962 class in the central part of the Apennines (Italy and San Marino). - Fitosociologia 38(1): 55-65.

— \& Casavecchia, S. 2010: The halophilous retro-dune grasslands of the Italian Adriatic coastline. - Braun-Blanquetia 46: 11-127.

—, - Estrelles, E. \& Soriano, P. 2013: Halocnemum M. Bieb. vegetation in the Mediterranean Basin. - Pl. Biosyst. 147(3): 536-547. doi: 10.1080/11263504.2013.832709

- , — \& Pesaresi, S. 2006: Spontaneous renaturalization processes of the vegetation in the abandoned fields (Central Italy). - Ann. Bot. 6: 65-94. 
—, 一, - Gangale, C. \& Uzunov, D. 2014c: New syntaxa for the prodrome of Italian vegetation. Pl. Biosyst. 148(4): 723-727. doi: 10.1080/11263504.2014.945508

— \& Galdenzi, D. 2012: Phytosociological analysis of the grasslands of Montagna dei Fiori (central Italy) and syntaxonomic review of the class Festuco-Brometea in the Apennines. - Pl. Sociol. 49(1): 91-112. doi: 10.7338/pls2012491/05

— \& - 2014: Syntaxonomic considerations of the Mediterranean vegetation dominated by perennial psammophilous graminaceous plants. - P. Sociol. 52(2 Sup1): 25-32. doi: $10.7338 / \mathrm{pls} 2014512 \mathrm{~S} 1 / 03$

— \& Zivkovic, L. 2014: Gli habitat costieri in Italia. - Pp. 238-243 in: Genovesi, P., Angelini, P., Bianchi, E., Dupré, E., Ercole, S., Giacanelli, V., Ronchi, F. \& Stoch, F. (eds.), Specie e habitat di interesse comunitario in Italia: distribuzione, stato di conservazione e trend. - Serie Rapporti 194/2014, Rome.

Blasi, C. (ed.) 2010: La vegetazione d'Italia con carta delle Serie di Vegetazione in scala 1:500000. - Roma.

—, Capotorti, G., Copiz, R., Guida, D., Mollo, B., Smiraglia, D. \& Zavattero, L. 2014: Classification and mapping of the ecoregions of Italy. - Pl. Biosyst. 148(6): 1255-1345. doi: $10.1080 / 11263504.2014 .985756$

— \& Frondoni, R. 2011: Modern perspectives for plant sociology: The case of ecological land classification and the ecoregions of Italy. - P1. Biosyst. 145(sup1.): 30-37. doi: $10.1080 / 11263504.2011 .602747$

—, Di Pietro, R. \& Filesi, L. 2004: Syntaxonomical revision of Quercetalia pubescenti-petraeae in the Italian Peninsula. - Fitosociologia 41(1): 87-164.

Bouzille, J.-B. \& De Foucault, B. 1988: Données phytosociologiques sur les ourlets et manteaux préforestiers en Vendée et régions limitrophes. - Doc. phytosociologiques 11: 57-66.

Brachetti, L. \& Conti, F. 2014: Monitoring of threatened plants in the "Sentina" Natural Reserve (Marche, Italy). - Pl. Sociol. 51(2 sup1): 39-46.

Braun-Blanquet, J. 1928: Pflanzensoziologie: grundzüge der vegetationskunde. - Berlin.

- 1932: Plant sociology; the study of plant communities, 1st ed. - New York, London.

Brullo, S. \& Di Martino, A. 1974: Vegetazione dell'Isola Grande dello Stagnone (Marsala). - Boll. Stud. Inf. Giard. Bot. Palermo 26: 15-62.

Bruno, F. \& Covarelli, G. 1968: I pascoli ei prati-pascoli della Valsorda (Appennino Umbro). - Not. Fitosociologico 5: 47-65.

Buffa, G., Filesi, L., Gamper, U. \& Sburlino, G. 2007: Qualità e grado di conservazione del paesaggio vegetale del litorale sabbioso del Veneto (Italia settentrionale). - Fitosociologia 44(1): 49-58.

Čarni, A. 2005: Trifolio-Geranietea vegetations in south and southeast Europe. - Acta Bot. Gall. 152(4): 483-496. doi: 10.1080/12538078.2005.10515508

Casavecchia, S., Biscotti, N., Pesaresi, S. \& Biondi, E. 2015: The Paliurus spina-christi dominated vegetation in Europe. - Biologia (Bratisl) 70(7) doi: 10.1515/biolog-2015-0100

Castelli, M. 1995: Brometi del versante padano dell'Appennino Ligure-Piemontese (Italia). Fitosociologia 30: 51-90.

Conti, F., Abbate, G., Alessandrini, A. \& Blasi, C. (eds.) 2005: An annotated checklist of the Italian vascular flora. - Rome.

-, Alessandrini, A., Bacchetta, G., Banfi, E., Barberis, G., Bartolucci, F., Bernardo, L., Bonacquisti, S., Bouvet, D., Bovio, M., Brusa, G., Del Guacchio, E., Foggi, B., Frattini, S., Galasso, G., Gallo, L., Gangale, C., Gottschlich, G., Grunanger, P., Gubellini, L., Iiriti, G., Lucarini, D., Marchetti, D., Moraldo, B., Peruzzi, L., Poldini, L., Prosser, F., Raffaelli, M., Santangelo, A., Scassellati, E., Scortegagna, S., Selvi, F., Soldano, A., Tinti, D., Ubaldi, D., Uzunov, D. \& Vidali, M. 2007: Integrazioni alla checklist della flora vascolare italiana. - Nat. Vicentina 10: 5-74. 
Corbetta, F. 1976: Lineamenti vegetazionali della Sacca di Bellocchio (Foce Reno). - Pp. 247-270 in: Scritti in memoria di Augusto Toschi. - Bologna.

Corticelli, S., Piccoli, F., Pellizzari, M. \& Dell'Aquila L. 1999: Carta della vegetazione 1: 35000. Parco Regionale del Delta del Po. Stazioni Centro storico e Valli di Comacchio. - Firenze.

Cutini, M., Fabozzi, F., Fortini, P., Armanini, E. \& Blasi, C. 1996: Coenological and phytosociological characterization of Latium. - Arch. Geobot 2(2): 113-122.

De Marco, G., Dinelli, A. \& Mossa, L. 1980: Aspetti della vegetazione costiera dell'Isola di S. Antioco (Sardegna sud-occidentale). - Ann. di Bot. 38(2): 173-191.

Del Vecchio, S., Prisco, I., Acosta, A. T. R. \& Stanisci, A. 2015: Changes in plant species composition of coastal dune habitats over a 20-year period. - AoB Plants 7: plv018-plv018. doi: 10.1093/aobpla/plv018

Dengler, J., Berg, C., Eisenberg, M., Isermann, M., Jansen, F., Koska, I., Löbel, S., Manthey, M., Päzolt, J., Spangenberg, A., Timmermann, T. \& Wollert, H. 2003: New descriptions and typifications of syntax within the project "Plant communities of Mecklenburg-Vorpommern and their vulnerability" - Part I. - Feddes Repert. 114: 587-631.

Di Pietro, R. 2011: New Dry Grassland Associations from the Ausoni-Aurunci Mountains (Central Italy) - Syntaxonomical Updating and Discussion on the Higher Rank Syntaxa. - Hacquetia 10(2): 183-231. doi: 10.2478/v10028-011-0011-9

Douda, J., Boublík, K., Slezák, M., Biurrun, I., Nociar, J., Havrdová, A., Doudová, J., Aćić, S., Brisse, H., Brunet, J., Chytrý, M., Claessens, H., Csiky, J., Didukh, Y., Dimopoulos, P., Dullinger, S., FitzPatrick, Ú., Guisan, A., Horchler, P. J., Hrivnák, R., Jandt, U., Kącki, Z., Kevey, B., Landucci, F., Lecomte, H., Lenoir, J., Paal, J., Paternoster, D., Pauli, H., Pielech, R., Rodwell, J. S., Roelandt, B., Svenning, J.-C., Šibík, J., Šilc, U., Škvorc, Ž., Tsiripidis, I., Tzonev, R. T., Wohlgemuth, T. \& Zimmermann, N. E. 2015: Vegetation classification and biogeography of European floodplain forests and alder carrs. - Appl. Veg. Sci. doi: 10.1111/avsc. 12201

Estrelles, E., Biondi, E., Galiè, M., Mainardi, F., Hurtado, A. \& Soriano, P. 2015: Aridity level, rainfall pattern and soil features as key factors in germination strategies in salt-affected plant communities. - J. Arid Environ. 117(August): 1-9. doi: 10.1016/j.jaridenv.2015.02.005

Feoli Chiappella, L. \& Poldini, L. 1993: Prati e pascoli del Friuli (NE Italia) su substrati basici. Stud. Geobot. 13: 3-140.

Géhu, J.-M. 1979: Pour une approche nouvelle des paysages végétaux: la symphytosociologie. Bull. Soc. Bot. Fr. Lettres Bot. 126(2): 213-223. doi: 10.1080/01811797.1979.10824391

- 1986: Qu'est-ce que l'Agropyretum mediterraneum Braun-Blanquet (1931) 1933? - Lazaroa 9: 343-354.

- 1988: L'analyse symphytosociologique et géosymphytosociologique de l'espace. Théorie et méthodologie. - Coll. phytosoc 17: 11-46.

— 2006: Dictionnaire de Sociologie et Synecologie végétales. - Berlin, Stuttgart

— \& Biondi, E. 1996: Synoptique des associations végétales du littoral adriatique italien. - Giorn. Bot. Ital. 130(1): 257-270. doi: 10.1080/11263509609439535

— \& - 1994: La végétation du littoral de la Corse: essai de synthèse phytosociologique. - BraunBlanquetia 13: 3-149.

-, Costa, M., Scoppola, A., Biondi, E., Marchiori, S., Peris, J. B., Franck, J., Caniglia, G. \& Veri, L. 1984: Essai synsystématique et synchorologique sur les végétations littorales italiennes dans un but conservatoire. - Doc. Phytosociol. 8: 393-473.

— \& Franck, J. 1988: Variations floristiques et Synchorologie des “Ammophilaies” européo-africaines. - Pp. 561-570 in: Homenaje a P. Montserrat . - Jaca, Huesca.

— \& Rivas-Martínez, S. 1981: Notions fondamentales de phytosociologie. - Pp. 5-53 in: Dierschke, H. (ed.), Syntaxonomie. Ber Intern. Symposium IV-V. - Vaduz. 
Heijmans, M. M. P. D., Mauquoy, D., van Geel, B. \& Berendse, F. 2008: Long-term effects of climate change on vegetation and carbon dynamics in peat bogs. - J. Veg. Sci. 19(3): 307-320. doi: $10.3170 / 2008-8-18368$

Hruska, K. 1982: Les paturages de Collelongo. - Pp. 211-236 in: Pedrotti, F. (ed.), Guide-itinéraire de l'excursion internationale de Phytosociologie en Italie centrale (2-11 juillet 1982) . - Camerino.

Hruska-Dell'Uomo, K. 1976: Contributo alla conoscenza dei pascoli aridi dell'Appennino marchigiano. - Not. Fitosociologico 12: 19-30.

Kirwan, M. L. \& Megonigal, J. P. 2013: Tidal wetland stability in the face of human impacts and sealevel rise. - Nature 504(7478): 53-60. doi: 10.1038/nature12856

Košir, P., Čarni, A. \& Di Pietro, R. 2008: Classification and phytogeographical differentiation of broad-leaved ravine forests in southeastern Europe. - J. Veg. Sci. 19(3): 331.342. doi: 10.3170/2008-8-18372

—, Casavecchia, S., Čarni, A., Škvorc, Ž., Zivkovic, L. \& Biondi, E. 2013: Ecological and phytogeographical differentiation of oak-hornbeam forests in southeastern Europe. - Pl. Biosyst. 147(1): 84-98. doi: 10.1080/11263504.2012.717550

Leon, C., Lucas, G. \& Synge, H. 1985: The value of information in saving threatened Mediterranean plants. - Pp. 177-196 in: Gomez-Campo, C. (ed.), Plant conservation in the Mediterranean area . - Dordrecht.

Medail, F. \& Quezel, P. 1997: Hot-Spots Analysis for Conservation of Plant Biodiversity in the Mediterranean Basin. - Ann. Missouri Bot. Gard. 84(1): 112. doi: 10.2307/2399957

Van der Meulen, F. \& Salman, A. H. P. M. 1996: Management of Mediterranean coastal dunes. Ocean Coast. Manag. 30(2-3): 177-195. doi: 10.1016/0964-5691(95)00060-7

Mossa, L. \& Biondi, E. 1992: Resoconto delle escursioni sul litorale sud-occidentale della Sardegna (27 e 28 ottobre 1989). - Colloq. Phytosociologiques 19: 739-760.

Mucina, L., Dengler, J., Bergmeier, E., Čarni, A., Dimopoulos, P., Jahn, R. \& Matevsky, V. 2009: New and validated high-rank syntaxa from Europe. - Lazaroa 30: 267-276.

Myers, N. 1990: The biodiversity challenge: Expanded hot-spots analysis. - Environmentalist 10(4): 243-256. doi: 10.1007/BF02239720

Ozenda, P. 1994: La végétation du continent européen. - Lausanne.

Papini, A., Trippanera, G. B., Maggini, F., Filigheddu, R. S. \& Biondi, E. 2004: New insights in Salicornia L. and allied genera (Chenopodiaceae) inferred from nrDNA sequence data. - P1. Biosyst. 138(3): 215-223. doi: 10.1080/11263500400006977

Pesaresi, S., Galdenzi, D., Biondi, E. \& Casavecchia, S. 2014: Bioclimate of Italy: application of the worldwide bioclimatic classification system. - J. Maps 10(4): 538-553. doi: 10.1080/17445647.2014.891472

Pezzetta, A. 2010: Gli elementi orientali Appennino-Balcanici, Illirici, Pontici e Sud-Est-Europei della flora italiana: origini e distribuzione geografica. - Ann. Ser. Hist. Nat. 20(1): 75-88.

Piccoli, F., Merloni, N. \& Corticelli, S. 1999: Carta della vegetazione del Parco Regionale del Delta del Po. Stazione Pineta di Classe e Salina di Cervia. Scala 1:25.000. - Firenze.

Pignatti, S. 1982: Flora d'Italia, 1-3. - Bologna.

- 1952: Introduzione allo studio fitosociologico della pianura veneta orientale con particolare riguardo alla vegetazione litoranea. - Arch. Bot. 28(4): 265-329.

- 1953: Introduzione allo studio fitosociologico della pianura veneta orientale con particolare con particolare riguardo alla vegetazione litoranea. - Arch. Bot. 29(3): 129-174.

Pirone, G., Ciaschetti, G., Di Martino, L., Cianfaglione, K., Giallonardo, T. \& Frattaroli, A. R. 2014: Contribution to the knowledge of the coastal vegetation of Abruzzo (central Adriatic). - Pl. Sociol. 52(2) (Suppl. 1): 57-64. doi: 10.7338/pls2014512S1/08

Poldini, L. 1989: La vegetazione del Carso isontino e triestino [Vegetation of Trieste and Gorizia karst]. - Trieste. 
—, Vidali, M., Biondi, E. \& Blasi, C. 2002: La classe Rhamno-Prunetea in Italia. - Fitosociologia 39(1 sup2): 145-162.

Pott, R. 2011: Phytosociology: A modern geobotanical method. - Pl. Biosyst. 145(sup1): 9-18. doi: $10.1080 / 11263504.2011 .602740$

Prisco, I., Carboni, M. \& Acosta, A. T. R. 2013: The Fate of Threatened Coastal Dune Habitats in Italy under Climate Change Scenarios Bohrer, G. (ed.). - PLoS One 8(7): e68850. doi: 10.1371/journal.pone.0068850

Rivas-Martínez, S. 2007: Mapa de series, geoseries y geopermaseries de vegetación de España:[Memoria del mapa de vegetación potencial de España]. Parte I. - Itinera Geobot. 17: 5-436.

- 2005: Notions on dynamic-catenal phytosociology as a basis of landscape science. - Pl. Biosyst. 139(2): 135-144. doi: 10.1080/11263500500193790

—, Sáenz, S. R. \& Penas, A. 2011: Worldwide bioclimatic classification system. - Glob. Geobot. 1: 1-634.

Sburlino, G., Buffa, G., Filesi, L., Gamper, U. \& Ghirelli, L. 2013: Phytocoenotic diversity of the NAdriatic coastal sand dunes-the herbaceous communities of the fixed dunes and the vegetation of the interdunal wetlands. - Pl. Sociol. 50(2): 57-77.

Sciandrello, S. \& Tomaselli, V. 2014: Coastal salt-marshes plant communities of the Salicornietea fruticosae class in Apulia (Italy). - Biologia (Bratisl). 69(1). doi: 10.2478/s11756-013-0283-2

Stanisci, A., Acosta, A. T. R., Carranza, M. L., De Chiro, M., Del Vecchio, S., Di Martino, L., Frattaroli, A. R., Fusco, S., Izzi, C. F. \& Pirone, G. 2014: EU habitats monitoring along the coastal dunes of the LTER sites of Abruzzo and Molise (Italy). - Pl. Sociol 51: 3-14.

Terzi, M. \& Di Pietro, R. 2013: Floristic characterization of the dry grasslands of the class FestucoBrometea Br.-Bl. et Tx. ex Klika et Hadac 1944 in the Adriatic Region. - Pp. 104-111 in: Calabrese, G., Pacucci, C., Occhialini, W. \& Russo, G. (eds.), IX National Biodiversity Conference. - Bari.

Theurillat, J. P. 1992: Etude et cartographie du paysage vegetal (symphytocoenologie) dans la région d'Aletsch (Valais, Suisse). Développement historique et conceptuel de la symphytocoenologie, niveaux de perception, méthodologie, applications. - Beitr Geobot Landesaufn Schweiz 68: 1-384.

Tüxen, R. 1979: Sigmeten und Geosigmeten, ihre Ordnung und ihre Bedeutug fur Wissenschaft, Naturschutz und Planung. - Biogeographie 16: 79-92.

Vagge, I. \& Biondi, E. 2004: The forest-edge vegetation of the alliance Trifolion medii Müller 1962 in the Northern Apennines (Italy). - Fitosociologia 41(2): 21-30.

Weber, H. E., Moravec, J. \& Theurillat, J. P. 2000: International Code of Phytosociological Nomenclature. 3rd edition. - J. Veg. Sci. 11(5): 739-768. doi: 10.2307/3236580

Willner, W., Theurillat, J. P., Pallas, J. \& Mucina, L. 2015: On the nomenclature of some high-rank syntaxa of European forest vegetation. - Phytocoenologia 45(1): 175-181. doi: $10.1127 /$ phyto/2015/0036

Addresses of the authors:

Edoardo Biondi ${ }^{1}$, Marina Allegrezza ${ }^{1}$, Simona Casavecchia ${ }^{1}$, Diana Galdenzi ${ }^{1}$, Roberta Gasparri ${ }^{1}$, Simone Pesaresi ${ }^{1}$, Pilar Soriano ${ }^{2}$, Giulio Tesei ${ }^{1} \&$ Carlo Blasi ${ }^{3}$,

${ }^{1}$ Department of Nutritional, Environmental and Agricultural Sciences (D3A), Polytechnic University of Marche, Italy. E-mail: e.biondi@univpm.it

${ }_{2}^{2}$ ICBiBE-Botanical Garden, Universitat de València, Quart 80, 46008 Valencia, Spain.

${ }^{3}$ Department of Environmental Biology, Sapienza University of Rome, Italy. 